\title{
Introduction to "Labor Unions in the Trump Administration: Courts, Congress, and the National Labor Relations Board"
}

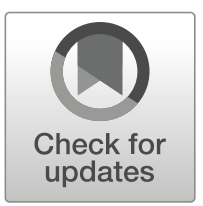

\section{Victor G. Devinatz ${ }^{1}$}

Published online: 21 December 2019

(C) Springer Science+Business Media, LLC, part of Springer Nature 2019

After three years in office, Trump's election to the US presidency in November 2016, has resulted in the passage of his Tax Cuts and Jobs Act (TCJA), his appointment of more than 150 politically conservative federal judges, which includes Supreme Court Justices Neil Gorsuch and Brett Kavanaugh, a foreign policy that can be characterized as promoting US nationalism, unilateralism, protectionism, and isolationism, combined with a coarsening of political rhetoric emanating from the White House. Additionally, as reported in The Washington Post, as of August 5, 2019, Trump has made some 12,019 false or misleading claims since assuming the presidency. According to Forbes contributor, Professor Laurence Kotlikoff of Boston University, under the TCJA, the richest $1 \%$ will receive average lifetime tax cuts of $\$ 278,540$ compared to, on average, lifetime tax reductions of $\$ 21,704$ for middle income earners and $\$ 4975$ for those at the bottom of the income spectrum. Moreover, since the average age of circuit court judges appointed by Trump is 49.4 years old, legal scholars contend that his judicial appointments will continue to impact the federal court system for decades. And the labor unions also have been negatively affected by Trump's presidency, for example, through the 2018 US Supreme Court's Janus v. American Federation of State, County, and Municipal Employees Union decision, which essentially implemented a right to work regime for all public sector unions and will continue to damage union strength and collective bargaining power long past Trump's tenure as US president.

The focus of this issue's "Perspectives" Section article is on how the Trump administration has harmed unions during his presidency's first three years. In this well-written and interesting essay, Dr. Raymond Hogler, Professor Emeritus of the Department of Management at Colorado State University, argues that although in 2016, Trump attained vital backing from noncollege educated white male workers who were represented by labor unions and had traditionally supported Democratic Party candidates, Trump's policies have had detrimental effects on not only these, but all, workers. Hogler defends his thesis regarding Trump's attack on labor

Victor G. Devinatz

vgdevin@ilstu.edu

1 Department of Management \& Quantitative Methods, Illinois State University, Normal, IL 61790-5580, USA 
through an examination of the actions of three legal regimes including the judiciary, the legislature and the National Labor Relations Board.

If any of the journal's readers are interested in responding to any essays published in the "Perspectives" Section or would like to write articles on any topics in the field of employee relations, please do not hesitate to contact me with your proposal. I welcome both practitionerbased and scholarly-based articles written from any one of a variety of theoretical perspectives. I hope that you enjoy this article and find it most illuminating. 